\title{
An Aircraft Observation of an Intrusion Process of Stratospheric Ozone into the Troposphere
}

\author{
by \\ Hisafumi Muramatsu, Toru Sasaki, Michio Hirota and Yukio Makino \\ Meteorological Research Institute, Tsukuba, Japan \\ (Received Sept. 27, 1983; Revised Dec. 14, 1983)
}

\begin{abstract}
The process of intrusion of stratospheric ozone into the troposphere, observed from an aircraft, is analysed with the use of routine aerological data. Stratospheric ozone is transported downward through the polar jet stream frontal zone to an altitude of $3 \mathrm{~km}$. Such transport is supported by the distributions of the potential vorticity, the water vapor and $\mathrm{CF}_{2} \mathrm{Cl}_{2}$ distributions.

The ozone in the troposphere seems to be diffused near the bottom of the frontal layer. The estimated magnitude of the Richardson number suggests that such diffusive mixing is much stronger at an altitude of $5 \mathrm{~km}$ than at $7 \mathrm{~km}$ in this case. The power spectral density of the ozone variations observed along the flight course shows that the turbulent motions with wavelengths of 5 to $20 \mathrm{~km}$ are important.
\end{abstract}

\section{Introduction}

The stratospheric-tropospheric exchanges play an important role in the distributions of ozone, aerosol and other substances in the stratosphere and the troposphere. Various transport processes between the stratosphere and the troposphere have been discussed so far:

(1) the mean meridional circulation

(2) large scale eddies and tropopause folding event

(3) seasonal variation of the tropopause height

(4) turbulent diffusion across the tropopause

(5) penetrating cumulonimbus towers in the tropics.

The intrusion of the stratospheric air and ozone into the troposphere through the polar jet stream front is one of the important processes. Analyzing distributions of ozone, potential vorticity and so on, this process has been studied by Staley (1960), Briggs and Roach (1963), Berggren (1965), Danielsen et al. (1970), Danielsen and Mohnen(1977), Shapiro $(1978,1980)$, Shapiro et al. (1980) and Muramatsu (1980).

The relative importance of this process among other exchange processes has not been well established. It is necessary to estimate the amounts of intruding air, ozone and other substances for the individual tropopause folding event and to estimate how much of these substances remains in the troposphere and how much returns into the stratosphere. Shapiro (1980) suggested an approximate $50 \%$ efficiency rate, i.e., half of the ozone entering the tropopause folding is lost in the troposphere. It is also suggested that the turbulent mixing in the troposphere plays an important role in the exchange procesess. 
In this report we will show the detailed structure of the folded tropopause and the distribution of ozone and other substances near the polar front jet stream system and the mixing process of transported ozone in the troposphere.

\section{Observations}

An aircraft observation was made between $00 \mathrm{Z}$ and $04 \mathrm{Z}$ on March 15, 1981 over the Kyoto-Osaka area. The flight course was determined with reference to the previous report (Muramatsu, 1980), in which we showed that the stratospheric air was transported into the troposphere over the Osaka area.

The synoptic flow pattern in the upper troposphere and the lower stratosphere at 00 Z, 15 March 1981, over Japan was dominated by two major jet stream branches. One was the polar front jet at $350 \mathrm{mb}$ level, with the axis cyclonically curved from the Ko-

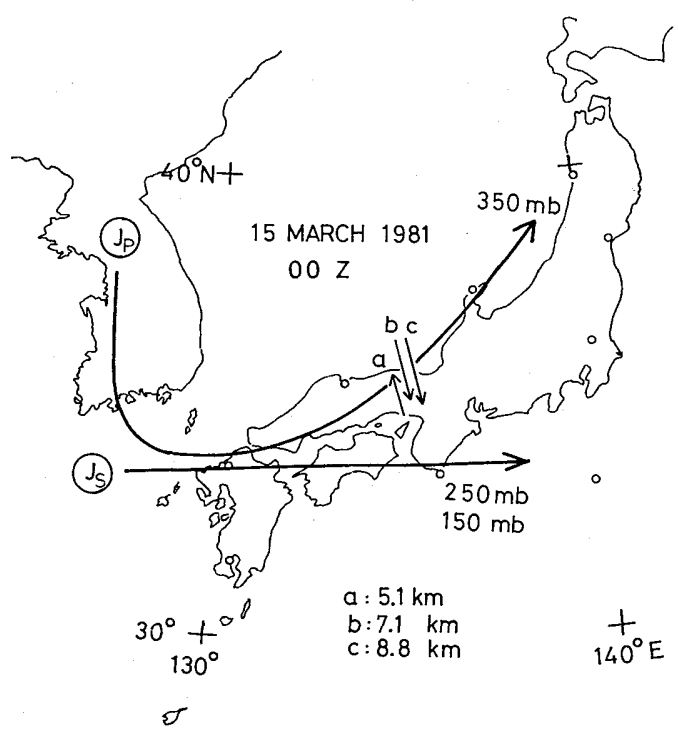

Fig. 1 Axes of the jet stream.

$\mathrm{J}_{\mathrm{P}}$ indicates the axis of the polar front jet and $\mathrm{J}_{\mathrm{s}}$ of the subtropical Jet. $\mathrm{a}, \mathrm{b}$, and $\mathrm{c}$ indicate the level flight courses at $5.1 \mathrm{~km}, 7.1 \mathrm{~km}$ and $8.8 \mathrm{~km}$, respectively.

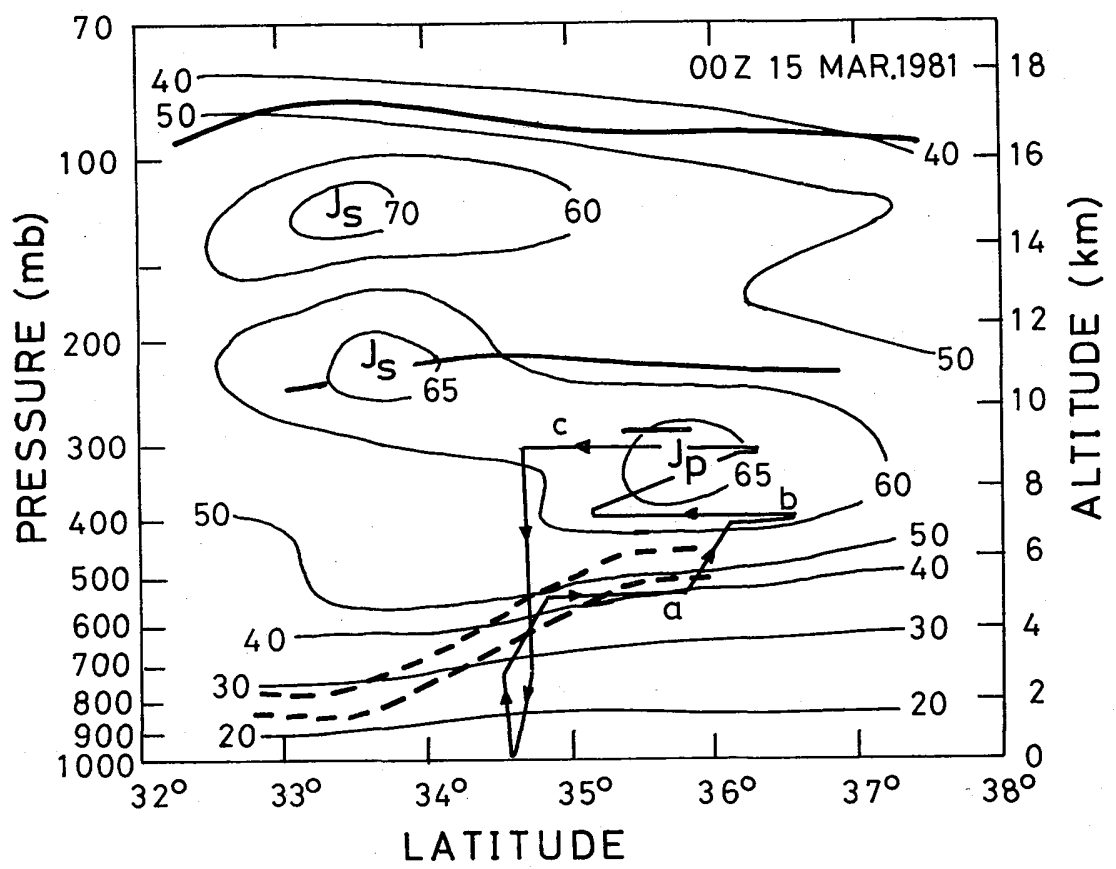

Fig. 2 Vertical cross-section along the $135^{\circ} \mathrm{E}$ meridian.

Solid lines are wind speed $(\mathrm{m} / \mathrm{sec})$; heavy solid lines, tropopauses; heavy broken lines, the frontal boundaries; solid lines with arrows, flight paths. $\mathrm{J}_{\mathrm{S}}$ and $\mathrm{J}_{\mathrm{P}}$ indicate the axes of the subtropical jet and polar front jet, respectively. $a, b$ and $c$ indicate the level flight courses. 
rean Peninsula to western Japan. The other was the subtropical jet whose axis was nearly straight. This had two maxima of wind speed at $250 \mathrm{mb}$ and $150 \mathrm{mb}$ levels (Fig. 1). Fig. 2 shows the vertical cross-section of the wind speed at $00 \mathrm{Z}, 15$ March 1981, obtained from the aerological data.

The observational flight course ran through and around the core of the jet stream, as shown by the solid line with arrows (Fig. 2). Three level-flight courses are shown by $\mathrm{a}, \mathrm{b}$ and $\mathrm{c}$ in Figs. 1 and 2. The vibrations of the aircraft were very weak between $0155 \mathrm{Z}$ and $0215 \mathrm{Z}$. This period corresponded to the time when the aircraft passed through the core of the jet stream. In other areas we encountered heavy vibrations espe- cially in the frontal zone.

Ozone concentrations were obtained with the response time of $10 \mathrm{sec}$ by means of UV absorption (Dasibi 1008-AH); corrections for pressure and temperature were automatically performed. Air temperature was sampled by the bead type thermistor every $10 \mathrm{sec}$. Air samples were collected in stainless-steel cylinders and the concentration of $\mathrm{CF}_{2} \mathrm{Cl}_{2}$ was determined in the laboratory.

\section{Analysis}

\subsection{The distribution of ozone, etc.}

The vertical ozone distribution along $135^{\circ}$ E meridian is shown in Fig. 3. The maxima of ozone concentration are seen at altitudes of about $8.5 \mathrm{~km}$ between $35^{\circ} 30^{\circ} \mathrm{N}$

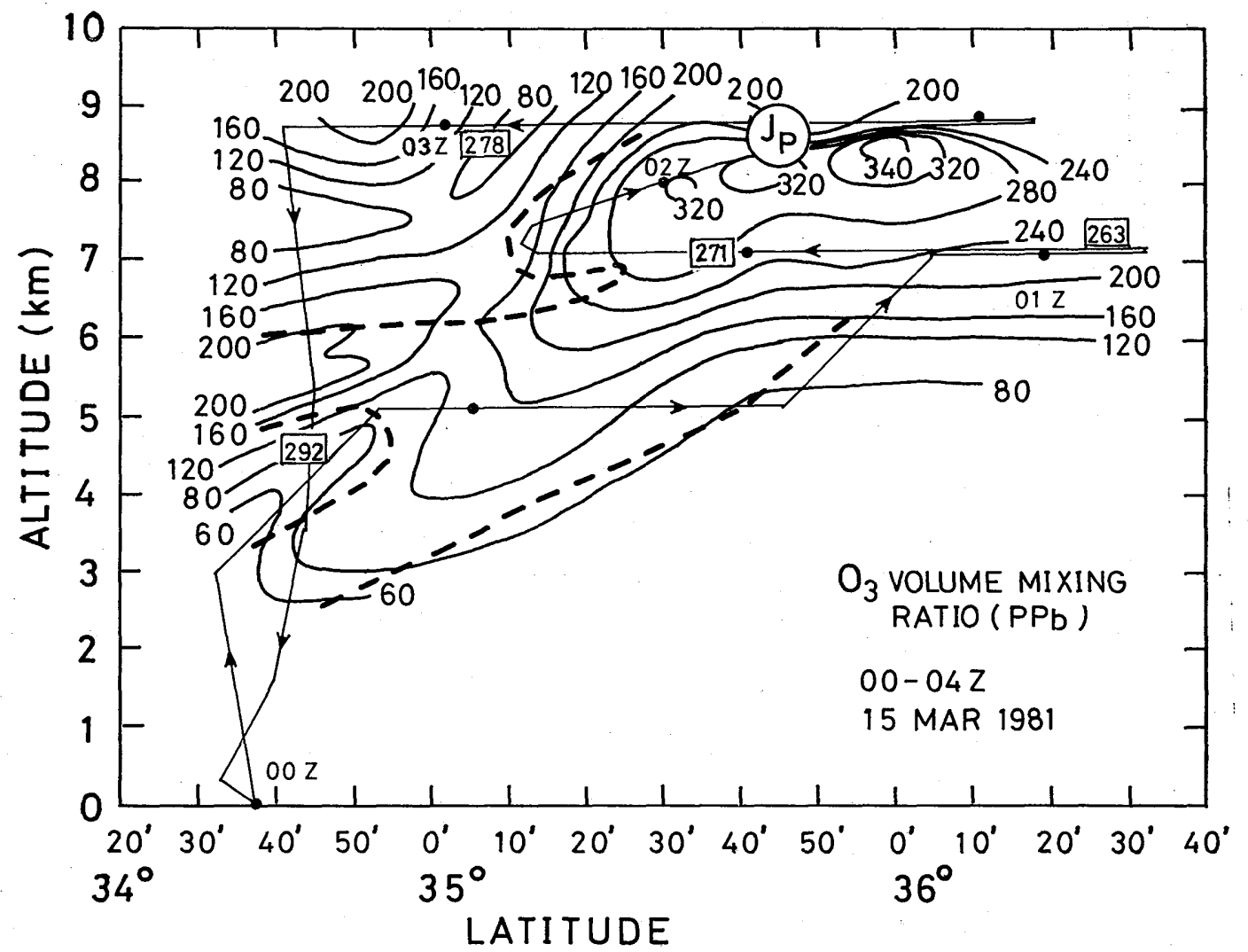

Fig. 3 Vertical cross-section of ozone along the $135^{\circ} \mathrm{E}$ meridian. Solid lines show the volume mixing ratio of ozone (ppbv); heavy broken lines, frontal boundaries; $J_{P}$, the axis of the polar front jet. The flight course is shown by solid lines with arrows and dots (every 0.5 hours). Data in the squares show the volume mixing ratio of $\mathrm{CF}_{2} \mathrm{Cl}_{2}$ (ppt). 


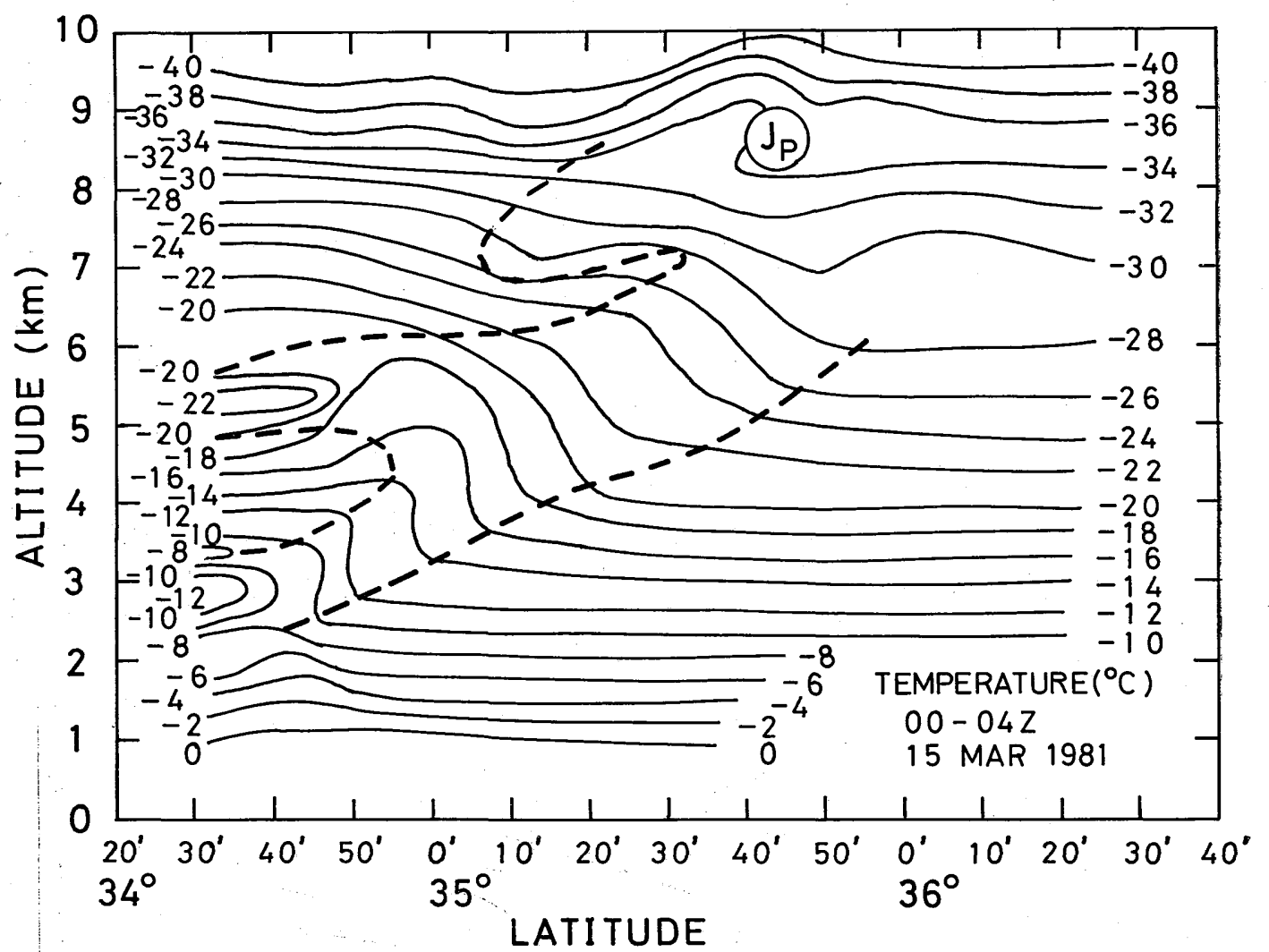

Fig. 4 Vertical cross-section of air temperature (solid lines, ${ }^{\circ} \mathrm{C}$ ).

Heavy broken lines show the frontal boundaries. $J_{P}$ shows the axis of the polar front jet.

and $36^{\circ} 00^{\prime} \mathrm{N}$. The layers of high ozone concentration stretch downward: one to an altitude of about $3 \mathrm{~km}$ and the other about 5.5 $\mathrm{km}$ at $34^{\circ} 30^{\prime} \mathrm{N}$. This feature suggests that ozone is transported downward in the jet stream front directly to an altitude of $3 \mathrm{~km}$.

The data in squares in Fig. 3 show the volume mixing ratio of $\mathrm{CF}_{2} \mathrm{Cl}_{2}$ (ppt). Its mixing ratios at an altitude of $7.1 \mathrm{~km}$ are 263 ppt and $271 \mathrm{ppt}$. The average volume mixing ratio of $\mathrm{CF}_{2} \mathrm{Cl}_{2}$ in the troposphere between December 1980 and March 1981 was $304 \mathrm{ppt}$ with a standard deviation of $10 \mathrm{ppt}$ (MRI's Technical Reports, 1982). The values at $7.1 \mathrm{~km}$ are, therefore, significantly lower than the average tropospheric value. From the long lifetime of $\mathrm{CF}_{2} \mathrm{Cl}_{2}$, we infer that the air mass in the frontal zone is originated from the stratosphere.. At lower al- titudes, say at about $4.6 \mathrm{~km}$, the mixing ratio of $\mathrm{CF}_{2} \mathrm{Cl}_{2}$ is $292 \mathrm{ppt}$, which is still lower than the average of the tropospheric value. This implies that the air mass at the lower layer between the two fingers of the frontal zone has air of stratospheric origin mixed in it.

The distribution of the temperature obtained from the aircraft is shown in Fig. 4. The frontal boundaries associated with the polar front jet are shown by heavy broken lines. The layer having a high ozone concentration agrees with this polar front. Two branches of the high ozone layer correspond with the two fingers of the front (Fig. 3).

The relative humidity in the frontal zone is very low as shown in Fig. 5. The region where the relative humidity is lower than $10 \%$ is hatched. Note that it is a rough es- 


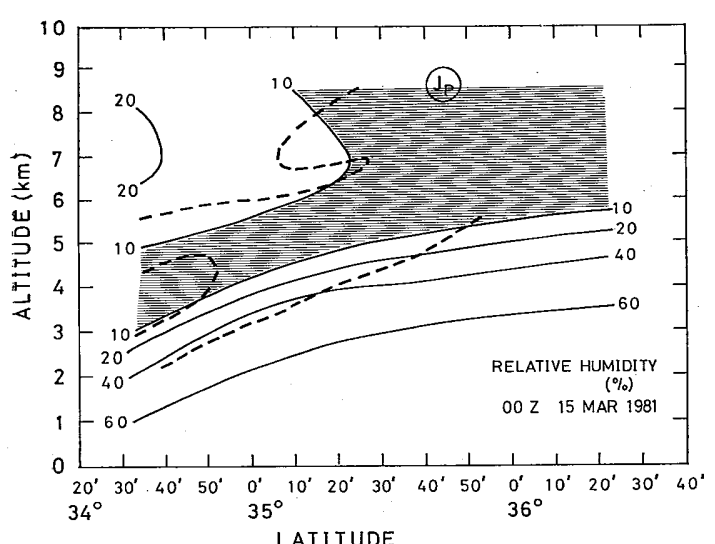

Fig. 5 Vertical cross-section of relative humidity (solid lines, \%).

Heavy broken lines show the frontal boundaries. $J_{P}$ shows the axis of the polar front jet.

timate because it is derived from the aerlogical data at $00 \mathrm{Z}, 15$ March 1981. For example, the two branches as seen in the frontal zone are not depicted in Fig. 5. The very low relative humidity in the frontal zone supports that the stratospheric air is transported downward into the troposphere in the polar front as shown in Fig. 3.

The aircraft reported on the regions of downward current around $0034 \mathrm{Z}$ and 0134 $Z$. These regions agree with the center of the layer of a high ozone concentration at altitudes of $5 \mathrm{~km}$ and $7 \mathrm{~km}$, respectively. This fact also supports the downward transport of ozone in the frontal zone.

\section{2 Potential vorticity}

As is well known, the potential vorticity, $P$, of an air parcel has a quasi-conservative property in adiabatic and frictionless motions. It is defined by

$$
P=-Q \frac{\partial \theta}{\partial p}
$$

where $Q$ is the absolute vorticity of the air parcel on an isentropic surface, $\theta$ is potential temperature and $p$ the pressure. $Q$ is defined by

$$
Q=\zeta_{\theta}+f
$$

where $\zeta_{\theta}$ is the vorticity measured on an isentropic surface and $f$ is the Coriolis parameter.

Generally the potential vorticity of air in the stratosphere is greater by one order of magnitude than in the tropospheric air. Therefore the potential vorticity can be used to mark the stratospheric air which has descended into the troposphere (Reed, 1955; Reed and Danielsen, 1959). Fig. 6 shows the potential vorticity on the $310 \mathrm{~K}$ isentropic surface; the observed upper branch of high ozone concentration at an altitude of $5.5 \mathrm{~km}$ over $34^{\circ} 40^{\prime} \mathrm{N}$ is on this surface. In order to trace back this high ozone region, we calculated the Montgomery stream function and then the potential vorticity on this surface.

The regions where the potential vorticity is greater than $6 \times 10^{-5} \mathrm{Kmb}^{-1} \mathrm{sec}^{-1}, 3 \times 10^{-5}$ $\mathrm{Kmb}^{-1} \mathrm{sec}^{-1}$ and $10^{-5} \mathrm{Kmb}^{-1} \mathrm{sec}^{-1}$ are marked by cross-hatching, heavy slant lines and thin slant lines, respectively. As the potential vorticity in the stratosphere is greater than $1 \times 10^{-5} \mathrm{Kmb}^{-1} \mathrm{sec}^{-1}$ (Shapiro, 1978), the air in the marked region in Fig. 6 is considered to be of stratospheric origin. The downward motion thus suggested is consistent with the time change of the potential vorticity distributions (Fig. 6). The air mass in the marked area is entirely in the troposphere at $00 \mathrm{Z}, 15 \mathrm{March}$ (Fig. 6(b)). The corresponding air mass at 12 hours before (Fig. 6(a)) was also in the troposphere but at higher altitudes than 12 hours later. In more detail, the center of the high potential vorticity lies at $460 \mathrm{mb}(6.0 \mathrm{~km}$ above m.s.l.) over $133^{\circ} \mathrm{E}, 36^{\circ} \mathrm{N}$ at $00 \mathrm{Z}, 15 \mathrm{March} ; 12$ hours before, it was at $370 \mathrm{mb}(7.5 \mathrm{~km}$ above m.s.l.) over $125^{\circ} \mathrm{E}, 38^{\circ} \mathrm{N}$. The average downward velocity during 12 hours at the center of the high potential vorticity is estimated to be $3.5 \mathrm{~cm} \mathrm{sec}^{-1}$. The location of such downward motion of the stratospheric air is at the southwestern and the southern part of the high level trough. This result agrees with the previous analysis(Muramatsu, 1980).

The vertical cross-section of the potential vorticity in the frontal zone calculated from 

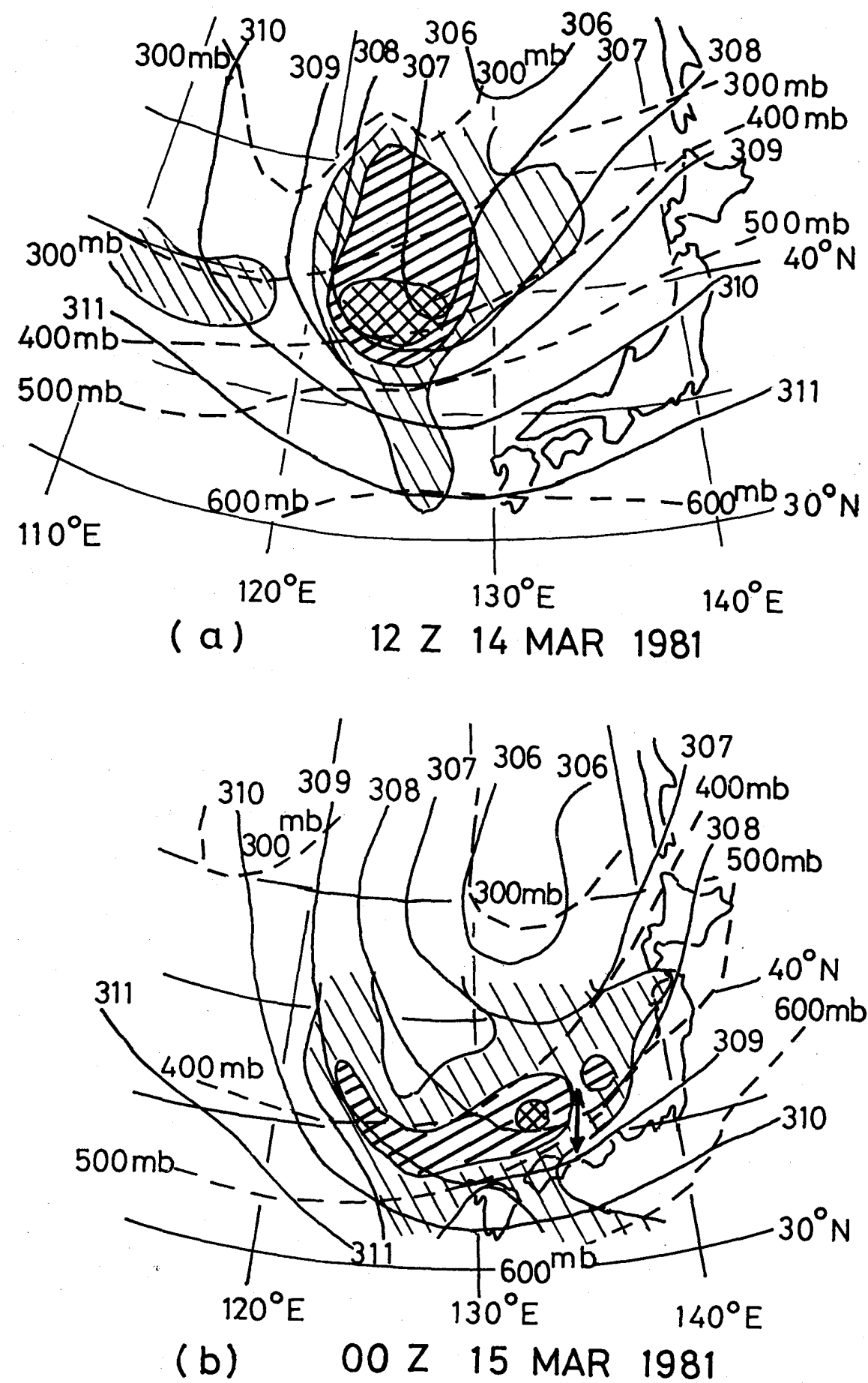

Fig. $6310 \mathrm{~K}$ isentropic chart for $12 \mathrm{Z} 14 \mathrm{March}$, (a); and $00 \mathrm{Z} 15 \mathrm{March}$, (b).

The regions where the potential vorticity is greater than $6 \times 10^{-5} \mathrm{Kmb}^{-1} \mathrm{sec}^{-1}, 3 \times 10^{-5}$ $\mathrm{Kmb}^{-1} \mathrm{sec}^{-1}$ and $10^{-5} \mathrm{Kmb}^{-1} \mathrm{sec}^{-1}$ are marked by cross-hatching, heavy slant lines and thin slant lines, respectively. Montgomery stream functions are shown by solid lines $\left(10^{7}\right.$ erg $\left.\mathrm{g}^{-1}\right)$, pressures by broken lines $(\mathrm{mb}) . \leftrightarrow$ shows the position of the observation. 


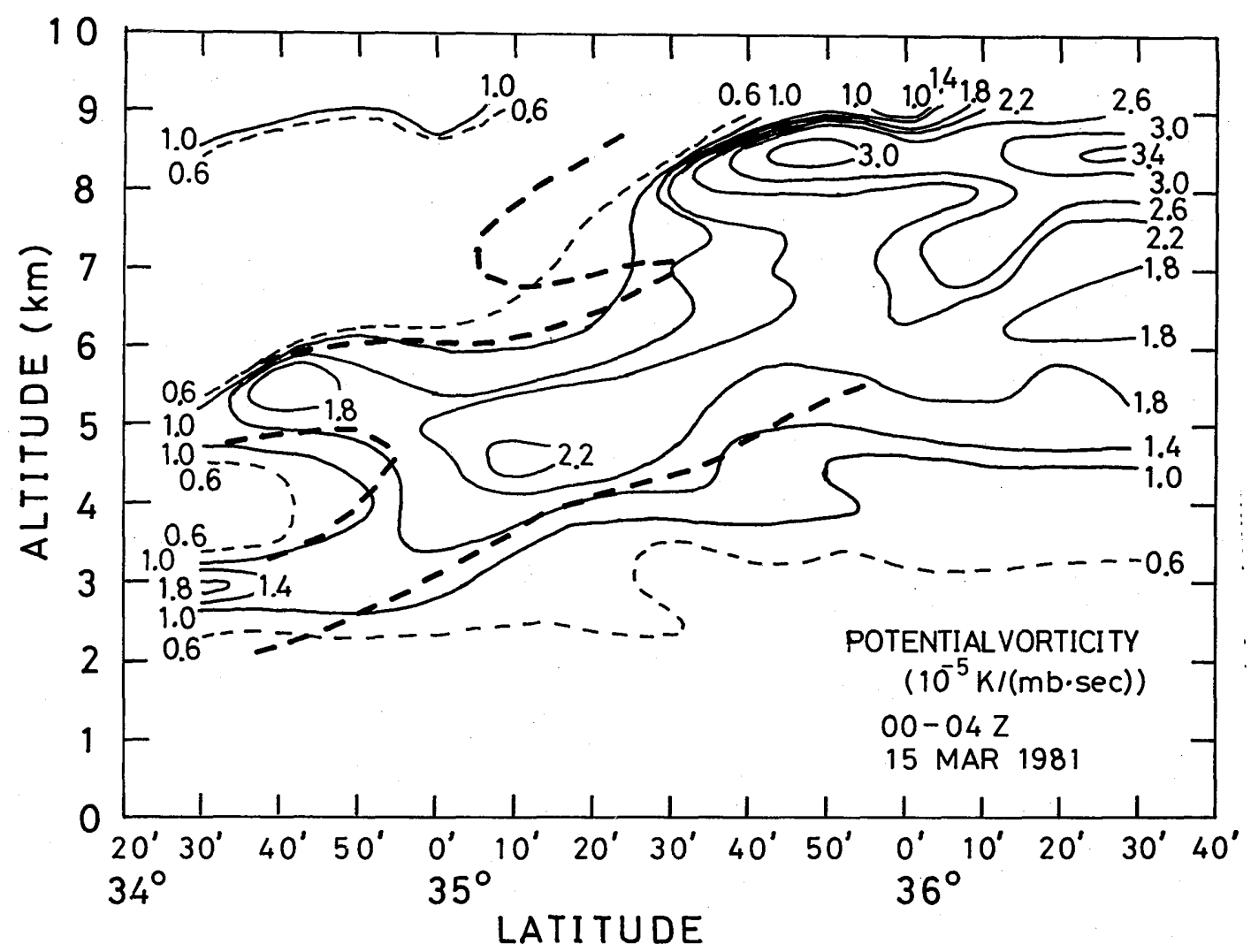

Fig. 7 Vertical cross-section of the potential vorticity (solid lines and thin broken lines, $10^{-5} \mathrm{Kmb}^{-1} \mathrm{sec}^{-1}$ ). Heavy broken lines show the frontal boundaries.

the temperature (Fig. 4) and the wind in the aerological data(Fig. 2) is shown in Fig. 7. The isentropic vorticity is approximated by $\left(\frac{\partial V}{\partial n}\right)_{\theta}+f$, where $\left(\frac{\partial V}{\partial n}\right)_{\theta}$ represents the horizontal wind shear in the plane along the $135^{\circ} \mathrm{E}$ meridian as measured at constant potential temperature $\theta$. The near zero-order discontinuity in potential vorticity at the level of maximum wind speed as shown by Shapiro $(1976,1978)$ is also found near $35^{\circ}$ $30^{\circ} \mathrm{N}$ at altitudes of 8 to $9 \mathrm{~km}$. Another discontinuity is seen over $34^{\circ} 40^{\circ} \mathrm{N}$ at altitudes of 5 to $6 \mathrm{~km}$.

It is also recognized that there is a high positive correlation between the ozone concentration (Fig. 3) and the potential vorticity (Fig. 7). We can see that the two fingers of high potential vorticity to the south of $34^{\circ} 50^{\prime} \mathrm{N}$ agree with those of high ozone concentration. The air mass in the jet stream frontal zone is of stratospheric origin as the potential vorticity is greater than $1 \times 10^{-5}$ $\mathrm{Kmb}^{-1} \mathrm{sec}^{-1}$. The lowest altitude at which the stratospheric air penetrates is about 3 $\mathrm{km}$ at $34^{\circ} 30^{\prime} \mathrm{N}$. At this point the ozone volume mixing ratio is about $60 \mathrm{ppb}$, which is a little higher than the average tropospheric mixing ratio at this altitude, i, e., 40 to50 ppb.

\section{3 Diffusion of ozone in the troposphere}

In order to estimate quantitatively the net amount of air and chemical constituents exchanged between the stratosphere and the troposphere in the vicinity of a jet stream frontal zone, it is important to determine the diabatic and turbulent mixing processes 

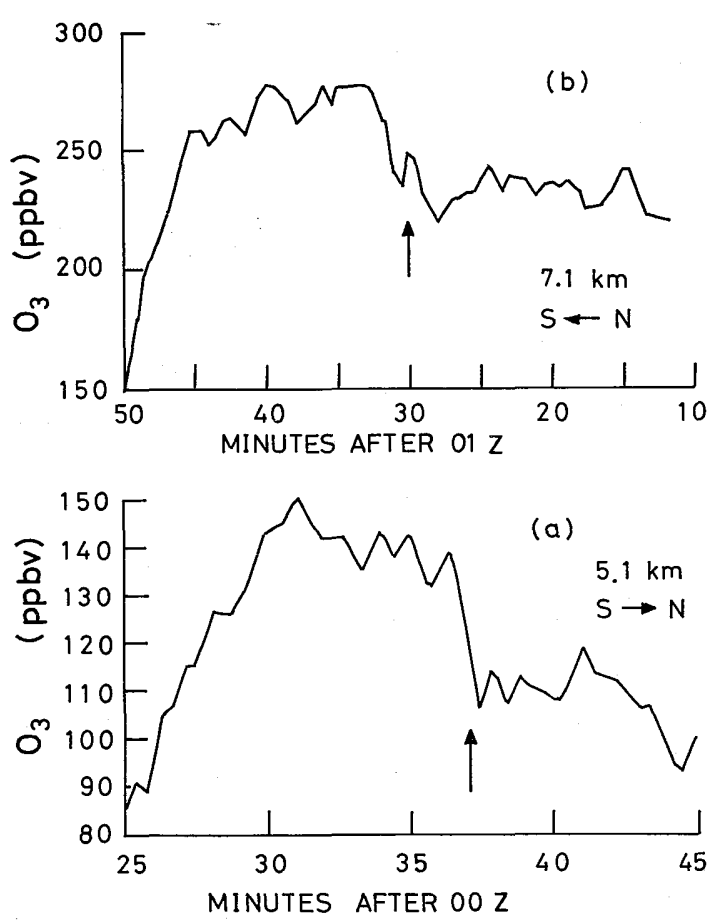

Fig. 8 Horizontal distribution of ozone in the frontal zone.

(a) $5.1 \mathrm{~km}$ above m.s. 1 . South to north flight course.

(b) $7.1 \mathrm{~km}$ above m.s. 1. North to south flight course.

Arrow shows the position of wind shear.

in the troposphere. Shapiro (1980) reported that turbulent mixing processes were of firstorder importance as a mechanism for stratospheric-tropospheric exchange in the vicinity of the frontal zone.

Three level flights were conducted along a north-south path perpendicular to the upper tropospheric flow. Two of them, at altitudes of 5.1 and $7.1 \mathrm{~km}$, traversed the jet stream frontal zone. The horizontal distributions of ozone mixing ratio in the frontal zone for these two flight tracks are shown in Fig. 8. We can see two characteristic features in these distributions: (1) ozone mixing ratio decreases steeply to the southern side of the frotal zone, (2) to the north of the ozone maximum layer, the ozone mixing ratio decreases sharply to a certain level, where it remains nearly constant. In regions sh-

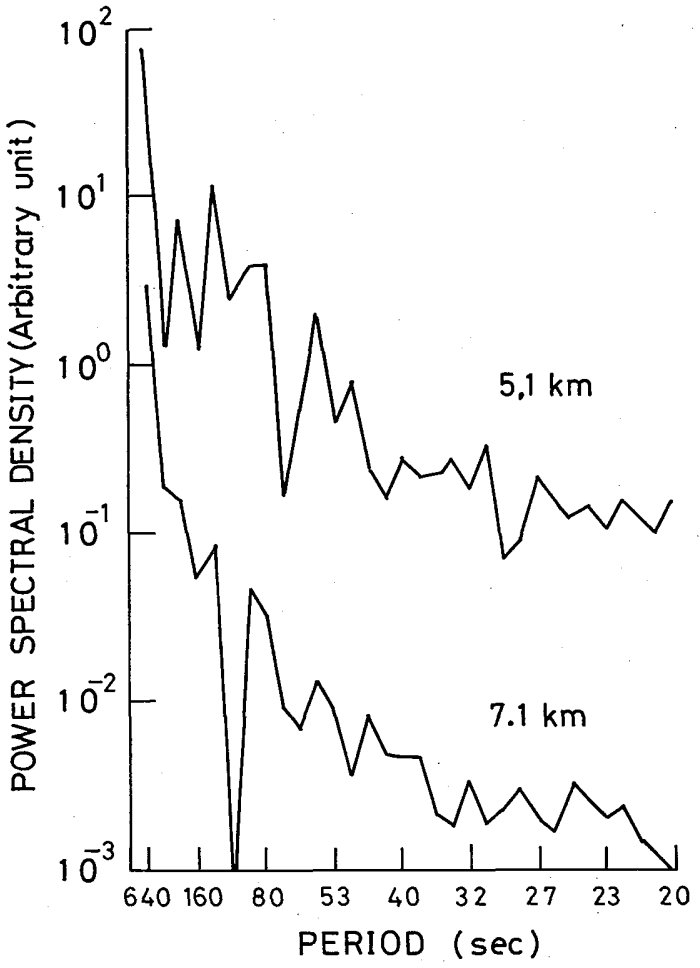

Fig. 9 Power spectra of ozone concentration in the frontal zone.

owing a sharp decrease of ozone concentration to the north of its maximum, the aircraft encountered a strong wind shear (shown by arrows in Fig. 8), i.e., downward wind to the south and upward wind to the north. (The absolute wind speed could not be estimated.) This implies the possibility that the mixing occurs to the northern half or at the bottom of the frontal zone.

In order to estimate the strength of the mixing and the frequency components of the turbulent motions, the power spectra of ozone variations are calculated. Fig. 9 shows the power spectra at altitudes of $5.1 \mathrm{~km}$ and $7.1 \mathrm{~km}$ calculated by the Fourier transform of the ozone mixing ratios. The power spectral density for $5.1 \mathrm{~km}$ is much higher than that for $7.1 \mathrm{~km}$. So it can be said that the mixing at $5.1 \mathrm{~km}$ is more intense than at $7.1 \mathrm{~km}$. At an altitude of $5.1 \mathrm{~km}$, the turbulent motions have the dominant peaks of period at 213, 128, 80 and $58 \mathrm{sec}$ (Fig. 9). 


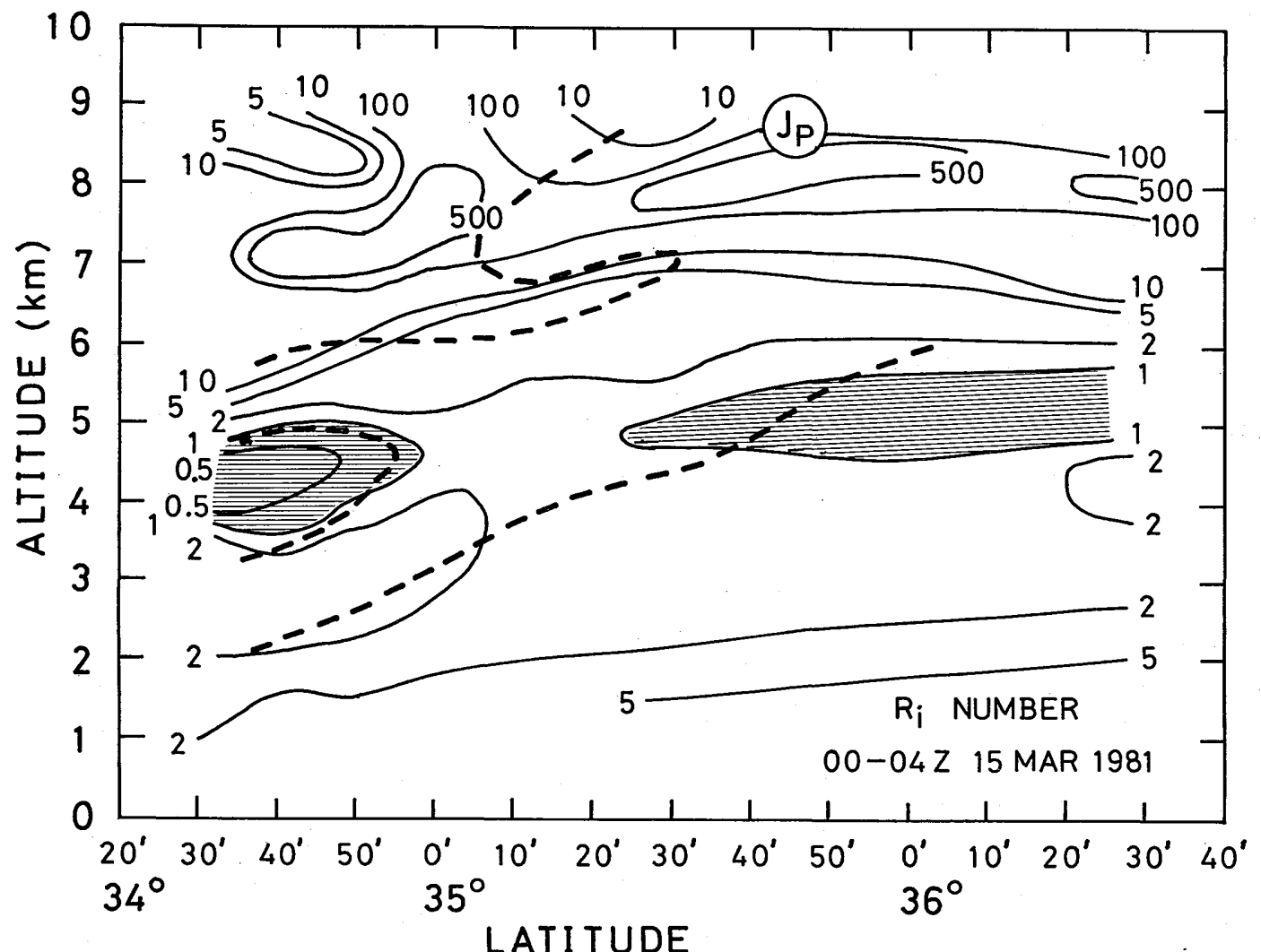

Fig. 10 Vertical cross-section of the Richardson number. Regions where $R_{i}<1.0$ are hatched. Heavy broken lines show the frontal boundaries. $J_{P}$ shows the axis the of polar front jet.

The flight speed of the aircraft being 100 $\pm 10 \mathrm{msec}^{-1}$, the wavelengths of the turbulent motions are estimated to be in the range of 5.8 to $21 \mathrm{~km}$ in the normal direction of the dominant westerly wind. This would correspond to the wavelike phenomenon of $10 \mathrm{~km}$ length or greater reported by Shapiro (1980). It is possible that this wavelike motion plays an important role in the exchange process. The mixing which is more intense at $5.1 \mathrm{~km}$ than at $7.1 \mathrm{~km}$ is supported by the distribution of the Richardson number shown in Fig. 10.

Fig. 10 shows the vertical cross-section of the Richardson number calculated from the temperature distribution observed by the aircraft and the wind of the aerological data. The layers of the low Richardson number lie at the bottom (or to the northern part) of the frontal zone. The Richardson number is lowest (lower than unity) between the altitudes of 4 and $5 \mathrm{~km}$, while it is between 6 and 20 at $7.1 \mathrm{~km}$. This fact shows that the layer at $5.1 \mathrm{~km}$ is more unstable than at $7.1 \mathrm{~km}$, which follows that the mixing is more intense at $5.1 \mathrm{~km}$ than at $7.1 \mathrm{~km}$.

This characteristic feature is common to Fig. 2 of Shapiro (1980). In this Figure the condensation nuclei concentration in the folded tropopause is about the same magnitude as that of planetary boundary layer, especially at the bottom of the frontal zone, which suggests that the mixing is intense in that region.

\section{Concluding remarks}

The intrusion process of stratospheric air, ozone and other constituents into the tropo. 
sphere and the associated mixings in the troposphere are analyzed from observational data. We show two characteristic features of the distribution of ozone in the frontal zone; (1) steep decrease of mixing ratio in the southern boundary, (2) relatively constant and high mixing ratio to the north of the wind shear. Ozone diffuses at the bottom (or to the northern part) of the frontal zone, where the Richardson number is lower than unity. In this region turbulent motions of wavelengths 5 to $20 \mathrm{~km}$ are considered to play an important role.

In order to determine the efficiency of the folding event for the exchage of ozone between stratosphere and troposphere, we must know the vertical and horizontal fluxes of ozone from observation of wind together with the ozone. It is also necessary to determine the role of the turbulent motions whose wavelengths are 5 to $20 \mathrm{~km}$. Observations of the lifetime of the intrusion process and the width of the folded tropopause parallel to the jet axis are necessary to assess the total amount of intruding ozone for individual cases.

\section{References}

Berggren, R., 1965: The vertical distribution of ozone over Arosa on 16 April 1962 and the synoptic situation. Tellus, 17, 180-193.

Briggs, J. and W. T. Roach, 1963: Aircraft observations near jet streams. Quart. J. R. Met. Soc., 89, 225-247.

Danielsen, E. F., R. Bleck, J. Shedlovsky, A. Wartburg, P. Haagenson, and W. Pollock, 1970: Observed distribution of radioactivity, ozone and potential vorticity associated with tropopause folding. J. Geophys. Res., 75, 23532361.
Danielsen, E. F. and V. A. Mohnen, 1977: Project Dustorm Repot: Ozone transport, in situ measurements, and meteorological analyses of tropopause folding. J. Geophys. Res., 82, 5867 -5877 .

Reed, R. J., 1955: A study of characteristic type of upper-level frontogenesis. J. Meteor., 12, 226-237.

Reed, R. J. and E. F. Danielsen, 1959: Fronts in the vicinity of the tropopause. Arch. Meteor. Geophys. Biokl. Ser. A, 11, 1-17.

Shapiro, M. A., 1976: The role of turbulent heat flux in the generation of potential vorticity in the vicinity of upper-level jet stream system. Mon. Wea. Rev., 104, 892-906

— 1978: Further evidence of the mesoscale and turbulent structure of upper level jet streamfrontal zone systems. Mon. Wea. Rev., 106, 1100-1111.

- 1980: Turbulent mixing within tropopause folds as a mechanism for the exchange of chemical constituents between the stratosphere and troposphere. J. Atmos. Sci., 37, 994-1004.

Shapiro, M. A.,- E. R, Reiter, R. D. Cadle, and W. A. Sedlacek, 1980: Vertical mass- and trace constituent transports in the vicinity of jet streams. Arch. Meteor. Geophys. Biokl. Ser. B, 28, 198-206.

Staley, D. O., 1960: Evaluation of potential-vorticity changes near the tropopause and the related vertical motions, vertical advection of vorticity, and transfer of radioactive debris from stratosphere to troposphere. J. Meteor., 17, 591-620.

Technical Reports of the Meteorological Research Institute No. 6, 1982: Meteorological Research Institute, Japan, pp 5-41, pp 93-154. (In Japanese)

Muramatsu, H., 1980: A case study of the transport of the stratospheric ozone into the tropo sphere. Papers in Meteor. and Geophys., 31, 97-105.

\title{
成層圈から対流圏へのオゾンの流入過程の航空機観測
}

\author{
村松久史・佐々木徹・広田道夫・牧野行雄
}

ジェット流近傍は成層圏と対流圏の空気・微量気体成分の交換が行なわれる場所の一つと考えられている。本報 告ではジェット流に伴ら前面付近のオゾン・ $\mathrm{CF}_{2} \mathrm{Cl}_{2}$ ・気温の航空機による観測值とルーチン高層観測資料を用いて, 成層圏から対流圏への流入過程の解析を行った。

成層圏からの空気・オゾン等はジェット流に伴ら寒帯前面に沿って高度 $3 \mathrm{~km}$ まで層状に侵入することが分った。 また侵入した前面内のオゾンは，前面の底部 (北側) で周囲の空気と混合される。この混合過程は高度 $5 \mathrm{~km}$ と $7 \mathrm{~km}$ とで比較すると $5 \mathrm{~km}$ ではるかに強いことが分った。また $5 \mathrm{~km}$ での混合には水平スケールが 5 〜 $20 \mathrm{~km} の$ 擾 乱が重要な役割を演じていることも示唆された。 